\title{
Genetic relationship of cowpea (Vigna unguiculata) varieties from Senegal based on SSR markers
}

\author{
F.A. Badiane ${ }^{1}$, B.S. Gowda ${ }^{2}$, N. Cissé ${ }^{3}$, D. Diouf ${ }^{1}$, O. Sadio ${ }^{4}$ and M.P. Timko ${ }^{2}$ \\ ${ }^{1}$ Plant Biotechnology Laboratory, Department of Plant Biology, \\ Faculty of Science and Technology, University Cheikh Anta Diop, \\ Dakar, Senegal \\ ${ }^{2}$ Department of Biology, University of Virginia, Charlottesville, VA, USA \\ ${ }^{3}$ National Center for Agricultural Research, \\ Senegalese Institute of Agricultural Research, Bambey, Senegal \\ ${ }^{4}$ Center of Bel-Air, Intitute of Development Research, Dakar, Senegal \\ Corresponding author: D. Diouf \\ E-mail: diaga.diouf@ucad.edu.sn
}

Genet. Mol. Res. 11 (1): 292-304 (2012)

Received July 11, 2011

Accepted November 1, 2011

Published February 8, 2012

DOI http://dx.doi.org/10.4238/2012.February.8.4

\begin{abstract}
Genetic diversity and phylogenetic relationships among 22 local cowpea (Vigna unguiculata) varieties and inbred lines collected throughout Senegal were evaluated using simple sequence repeat molecular markers. A set of 49 primer combinations were developed from cowpea genomic/expressed sequence tags and evaluated for their ability to detect polymorphisms among the various cowpea genotypes. Forty-four primer combinations detected polymorphisms, with the remaining five primer sets failing to yield PCR amplification products. From one to 16 alleles were found among the informative primer combinations; their frequencies ranged from 0.60 to $0.95($ mean $=0.79)$. The genetic diversity of the sample varied from 0.08 to $0.42($ mean $=0.28)$. The polymorphic information content ranged from 0.08 to 0.33 (mean $=0.23$ ). The local varieties clustered in the same group, except 53-3, 58-53, and 58-57; while Ndoute yellow pods, Ndoute violet pods and Baye Ngagne were in the
\end{abstract}


second group. The photosensitive varieties (Ndoute yellow pods and Ndoute violet pods) were closely clustered in the second group and so were inbred line Mouride and local cultivar 58-57, which is also one of the parents for inbred line Mouride. These molecular markers could be used for selection and identification of elite varieties for cowpea improvement and germplasm management in Senegal.

Key words: Cowpea; Vigna unguiculata; Genetic diversity; Germplasm management; Microsatellites

\section{INTRODUCTION}

Cowpea [Vigna unguiculata (L.) Walp.] is the most important grain legume crop grown in sub-Saharan Africa. Cowpea plays a major role in human nutrition not only because of its good protein quality with a high nutritional value but also because cowpea hay is critical for feeding animals during the dry season in many parts of West Africa. Moreover, cowpea is a valuable source of income for farmers and grain traders of this region (Langyintuo et al., 2003; Timko et al., 2007; Timko and Singh, 2008; Diouf, 2011). In addition, its nitrogen-fixing ability is extremely valuable when used in crop rotation with cereal crops (Timko et al., 2007). The majority ( $64 \%)$ of the cowpea production, 12.5 million tons worldwide takes place in the sub-Saharan Africa (Langyintuo et al., 2003). Cowpea grows in a wide range of soil $\mathrm{pH}$ and temperature $\left(18-28^{\circ} \mathrm{C}\right)$ compared to other legumes and also has a considerable adaptation to high temperatures and drought compared to other crop species (Ehlers and Hall, 1996).

Cowpea breeding and genetic improvement programs around the world are mainly focused on combining desirable agronomic characteristics, e.g., time to maturity, photoperiod sensitivity, plant type, and seed quality with resistance to the major diseases, insect pests or parasites that agronomically afflict adapted cowpea cultivars (Timko et al., 2007; Timko and Singh, 2008). Currently, depending upon the source of the characteristics being introgressed, close to a decade, more or less, would be required to breed a superior improved line using traditional breeding strategies. Leveraging emerging molecular makerbased tools for tracking single genes and quantitatively inherited traits linked to major disease and pest resistances, as well as the establishment of breeder-friendly protocols for maker-assisted selection (MAS) in the breeding process, can substantially reduce this time frame. Moreover, the knowledge of the genetic diversity available within the local and regional germplasm collections can enhance the overall effectiveness of cowpea improvement programs (Hegde and Mishra, 2009).

Genetic diversity of wild and cultivated cowpeas has been studied in the past, using a variety of approaches including analysis of morphological and physiological traits (Perrino et al., 1993; Ehlers and Hall, 1996), allozymes (Panella and Gepts, 1992; Pasquet, 1993), seed storage proteins (Fotso et al., 1994), chloroplast DNA polymorphisms (Vaillancourt and Weeden, 1992); random amplified polymorphic DNA (RAPD; Mignouna et al., 1998; Nkongolo, 2003; Diouf and Hilu, 2005); restriction fragment length polymorphisms (RFLP; Fatokun et al., 1993); amplified fragment length polymorphisms (AFLP; Tosti and Negri, 2002; Fang et al., 2007); DNA amplification fingerprinting (Spencer et 
al., 2000; Simon et al., 2007); inter-simple sequence repeat (Ghalmi et al., 2010); analysis of simple sequence repeats (SSRs; Li et al., 2001; Uma et al., 2009; Gupta and Gopalakrishma, 2010; Asare et al., 2010); sequence tagged microsatellite sites (Choumane et al., 2000), and cross species SSRs from Medicago (Sawadogo et al., 2010). Of these techniques, analysis of SSRs have shown to be particularly useful since these sequences, besides being abundant and randomly distributed throughout the both intergenic and transcribed regions of the eukaryotic genomes, are highly polymorphic, inherited codominantly and reproducible, with simple screening requirements (Tautz, 1989). SSR have been widely used in genome analysis, genetic mapping, and studies of genetic variation in germplasm of legume crops (Li et al., 2001; Hong et al., 2010; Cieslarová et al., 2010). In addition, some studies have shown that SSRs can detect more polymorphisms than RFLPs, RAPDs and AFLPs in legumes (e.g., peanut) (Barkley et al., 2007). SSRs have also been extensively used in genotype identification, seed purity evaluation and variety protection (Senior et al., 1998), pedigree analysis (Ayres et al., 1997), and genetic mapping of simple and quantitative traits and MAS (Chen et al., 1997). Because of their usefulness, microsatellites are one of the molecular markers recommended in a system of distinctness, uniformity and stability testing by the International Union for the Protection of new varieties of plants (UPOV-BMT: BMT/36/10, 2002). Currently, the availability of sequence databases in GenBank offers a great opportunity for the identification and development of SSR markers by reducing time-consuming and the cost of developing microsatellite-enriched libraries (Gupta and Gopalakrishma, 2010).

With the exception of the study of Diouf and Hilu (2005), who examined 11 cowpea varieties and inbred lines using SSR markers, the diversity and relatedness of cowpea germplasm in Senegal are poorly understood. The aim of present study was to assess the genetic diversity and relationships between some important local cowpea varieties and inbreed lines from the Senegalese germplasm for better management of phytogenetic resources, including the nine cowpea varieties and inbred lines previously analyzed.

\section{MATERIAL AND METHODS}

\section{Plant materials}

Twenty-two cowpea varieties including local cultivars and inbred lines from the Senegalese national germplasm were selected for the present study (Table 1). These included 9 of the selected by Diouf and Hilu (2005) for diversity analysis using RAPD and SSR. They were grown in the greenhouse at University of Virginia. Three individual plants per cultivar/ inbred line were sampled from which leaves were collected for DNA extraction from 15-dayold seedlings. The leaves were frozen in liquid nitrogen and stored at $-80^{\circ} \mathrm{C}$ until used.

\section{DNA isolation and quantification}

Total DNA was extracted using the DNAzol ES ${ }^{\circledR}$ as per the protocol described by the manufacturer with slight modifications. Leaf samples were ground in liquid nitrogen in a precooled mortar with a pestle and the powder was transferred to a 2.0-mL Eppendorf tube containing $0.75 \mathrm{~mL}$ DNAzol. This was mixed and incubated at room temperature for 


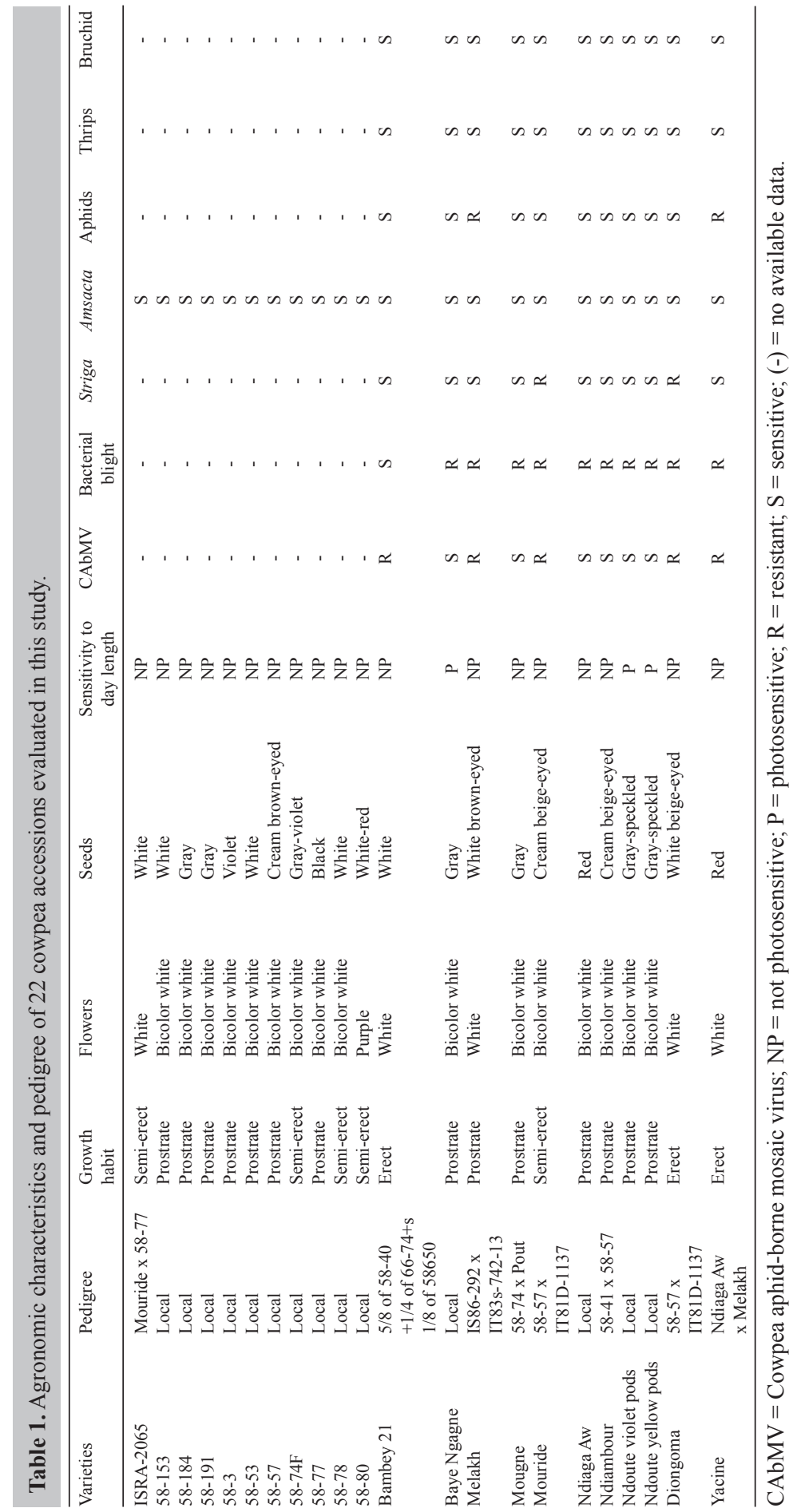


$5 \mathrm{~min}$ and $0.75 \mathrm{~mL}$ chloroform was added and then the solution was vortexed $(20 \mathrm{~s})$ and incubated at room temperature for $5 \mathrm{~min}$. The solution was centrifuged in a microcentrifuge at $13,000 \mathrm{rpm}$ for $10 \mathrm{~min}$. Supernatant was transferred to a new $1.5-\mathrm{mL}$ tube, $1 \mathrm{~mL}$ ethanol $(100 \%)$ was added and mixed well by gently inverting several times. The tubes were incubated at room temperature for $5 \mathrm{~min}$ and centrifuged at $5000 \mathrm{rpm}$ for $4 \mathrm{~min}$. Pelleted DNA was washed with $1 \mathrm{~mL} \mathrm{70 \%} \mathrm{ethanol,} \mathrm{centrifuged} \mathrm{at} 5000 \mathrm{rpm}$ for $5 \mathrm{~min}$. DNA was dried at room temperature for $1 \mathrm{~h}$, dissolved in $100 \mu \mathrm{L} \mathrm{TE}, \mathrm{pH} 8$, quantified with spectrophotometer ND-1000 (Thermo Scientific, Wilmington, DE, USA) and stored at $4{ }^{\circ} \mathrm{C}$.

\section{PCR amplification of DNA and electrophoresis}

PCR amplification was carried out in a $0.2-\mathrm{mL}$ PCR tube with a reaction volume of 25 $\mu \mathrm{L}$, containing $2.5 \mu \mathrm{L} 10 \mathrm{X}$ PCR buffer, $1 \mu \mathrm{M}$ of each primer (Table 2), $1 \mathrm{mM}$ of each dNTPs, 0.5 U Taq DNA polymerase and $50 \mathrm{ng}$ DNA. The tubes were placed in an Eppendorf Mastercycler Gradient thermocycler programmed for initial denaturation at $94^{\circ} \mathrm{C}$ for $1 \mathrm{~min}$ followed by 35 cycles of $30 \mathrm{~s}$ at $94^{\circ} \mathrm{C}, 30 \mathrm{~s}$ at $55^{\circ} \mathrm{C}, 1 \mathrm{~min}$ at $72^{\circ} \mathrm{C}$, and a final extension of $10 \mathrm{~min}$ at $72^{\circ} \mathrm{C}$. PCR products were resolved on a polyacrylamide gel (6\%), using $0.5 \mathrm{X}$ TBE containing $1 \mathrm{mg} /$ $\mathrm{mL}$ ethidium bromide with a vertical electrophoresis apparatus (C.B.S. Scientific Co., Delmar, CA, USA, model C-DASG-400-50) at $300 \mathrm{~V}$. The gel was photographed using AlphaImager 2200 (Alpha Innotech, Santa Clara, CA, USA) under UV transilluminator.

\section{Scoring SSR data and statistical analysis}

The bands that were not polymorphic with at least one of the samples were not scored for analysis because they are not informative. The informative bands were scored on the basis of the presence/absence (1/0), used as raw data to generate a matrix, which was subjected to principal component analysis and analysis of molecular variance (AMOVA).

\section{Multivariate analysis}

A normalized analysis of principal component using statistical package ADE-4 coupled with a hierarchical cluster analysis was carried out to group the varieties according to their similarity. The polymorphic bands were considered as variable but the 22 cowpea varieties were projected in a plane including the two first axes. An ascending hierarchical clustering of the individuals was performed by using the coordinates of the individuals on the factorial axes as similarity matrix, the Euclidean distance and the Ward method. The R (version R-2.9.0, ADE4 package) software (R Development Core Team, 2011) was used to generate a dendrogram. The similarities showed on the dendrogram ranged from 10 (high similarity) to 35 (low similarity).

\section{RESULTS}

\section{SSR polymorphism}

A set of 49 pairs of primers designed to amplify known SSR regions in cowpea were used to analyze genetic diversity of 22 cowpea varieties including local accessions and inbred lines. These 
Table 2. List of primer combinations used to amplify simple sequence repeats (SSRs) in this study.

\begin{tabular}{|c|c|c|c|}
\hline Primer codes & Primer sequences $\left(5^{\prime}-3^{\prime}\right)$ & Number of alleles & Number of bands \\
\hline $\mathrm{CP} 31, \mathrm{CP} 32$ & $\begin{array}{l}\text { 5'-CCTAAGCTTTTCTCCAACTCCA-3' } \\
\text { 5'-CAAGAAGGAGGCGAAGACTG-3' }\end{array}$ & 3 & 24 \\
\hline SSR-6206 & $\begin{array}{l}\text { 5'-AGGCATGCATTCATCTTTCC-3' } \\
\text { 5'-GCAGTCATAACCCCAAAACAA-3' }\end{array}$ & 3 & 66 \\
\hline SSR-6209 & $\begin{array}{l}\text { 5'-AAACAAGATAACTCTAAGGCAGAACAA-3' } \\
\text { 5'-ACGGTGGAAGGTTTAACTGGT-3' }\end{array}$ & 5 & 35 \\
\hline SSR-6211 & $\begin{array}{l}\text { 5'-TGTCCTCAATTTCAATAACAAGTTT-3' } \\
\text { 5'-AACAGTTGGTCGGATACGAAA-3' }\end{array}$ & 2 & 10 \\
\hline SSR-6243 & $\begin{array}{l}\text { 5'-GTAGGGAGTTGGCCACGATA-3' } \\
\text { 5'-CAACCGATGTAAAAAGTGGACA-3' }\end{array}$ & 4 & 44 \\
\hline SSR-6251 & $\begin{array}{l}\text { 5'-CCAAGAAAGGCCACTAGCAG-3' } \\
\text { 5'-GACGTTGAGCAGGGAAACTC-3' }\end{array}$ & 1 & 22 \\
\hline SSR-6255 & $\begin{array}{l}\text { 5'-TGTTCCAACCTTGAAATAGTATCAT-3' } \\
\text { 5'-TTGCAGGTCACCACTCTCTG-3' }\end{array}$ & 2 & 44 \\
\hline SSR-6257 & $\begin{array}{l}\text { 5'-TGCTTTTGTAAAAGGGTGGAA-3' } \\
\text { 5'-ACTTGGACGGAACAGCAGAT-3' }\end{array}$ & 4 & 47 \\
\hline SSR-6258 & $\begin{array}{l}\text { 5'-GGTTTCCTAGTTGGGAAGGAA-3' } \\
\text { 5'-ATTATGCCATGGAGGGTTCA-3' }\end{array}$ & 3 & 25 \\
\hline SSR-6281 & $\begin{array}{l}\text { 5'-GCATCAATTTGAGCGAGGAT-3' } \\
\text { 5'-GAGTGACATTTCCGCGTCTT-3' }\end{array}$ & 2 & 44 \\
\hline SSR-6284 & $\begin{array}{l}\text { 5'-GAAAGGGAAGGATTATGGGATA-3' } \\
\text { 5'-GGCAAATAGCGGGGTAGAGT-3' }\end{array}$ & 4 & 65 \\
\hline SSR-6291 & $\begin{array}{l}\text { 5'-TCATGAGTTTCCACACACCAA-3' } \\
\text { 5'-CCTTCGTATGTATATGTGGCTACTG-3' }\end{array}$ & 2 & 44 \\
\hline SSR-6292 & $\begin{array}{l}\text { 5'-AAGGGTGCACTGGTAGAGGA-3' } \\
\text { 5'-GCTCACTTTGTGCATGTTCC-3' }\end{array}$ & 6 & 48 \\
\hline SSR-6302 & $\begin{array}{l}\text { 5'-TGGAGGCATAAAAATGACACCT-3' } \\
\text { 5'-AAGCTGATTGTGGAACCATTG-3' }\end{array}$ & 4 & 60 \\
\hline SSR-6304 & $\begin{array}{l}\text { 5'-CTGGAACAAGTCGAGATGGAA-3' } \\
\text { 5'-CCATCCCCACCAAAAGT-3' }\end{array}$ & 6 & 51 \\
\hline SSR-6314 & $\begin{array}{l}\text { 5'-TGGAGGCATAAAAATGACACCT-3' } \\
\text { 5'-TGAAGCTGATTGTGGAACCAT-3' }\end{array}$ & 4 & 60 \\
\hline SSR-6323 & $\begin{array}{l}\text { 5'-CAAAGGGTCATCAGGATTGG-3' } \\
\text { 5'-TTTAAGCAGCCAAGCAGTTGT-3' }\end{array}$ & 4 & 28 \\
\hline SSR-6876 & $\begin{array}{l}\text { 5'-GGAATTGAAATTGATCTAATG-3' } \\
\text { 5'-GTATTTAAGTGGCTTATGAGGTTG-3' }\end{array}$ & 4 & 22 \\
\hline SSR-6906 & $\begin{array}{l}\text { 5'-GGACATTTAGGATTGGGTGG-3' } \\
\text { 5'-CAAGAATGTCTGAAACTAATATGC-3' }\end{array}$ & 7 & 82 \\
\hline SSR-6531 & $\begin{array}{l}\text { 5'-TGTATTTTAGAAGATGGAAG-3' } \\
\text { 5'-GGTTTTGTTCTCATTCATTC-3' }\end{array}$ & 2 & 16 \\
\hline SSR-6533 & $\begin{array}{l}\text { 5'-TCCTTCAAAATAACTGTCAA-3' } \\
\text { 5'-CGGCCATTAAATTGTGATC-3' }\end{array}$ & 7 & 30 \\
\hline SSR-6540 & $\begin{array}{l}\text { 5'-GGACATTTAGGATTGGGTGG-3' } \\
\text { 5'-CCATAGGTTAAACTTATTGTACTC-3' }\end{array}$ & 14 & 116 \\
\hline SSR-6545 & $\begin{array}{l}\text { 5'-GCTTGATTTCTTGTTTCCTT-3' } \\
\text { 5'-CAATCAATCAAGTAAGCAAG-3' }\end{array}$ & 8 & 29 \\
\hline SSR-6550 & $\begin{array}{l}\text { 5'-GGTGACATTATATTCTTCTG-3' } \\
\text { 5'-AAGTTACACCAATGCCAAAAAC-3' }\end{array}$ & 7 & 41 \\
\hline SSR-6553 & $\begin{array}{l}\text { 5'-ACTTTGTGACAATAGTGCTAC-3' } \\
\text { 5'-AAGGATTCTCAGATGATTAA-3' }\end{array}$ & 5 & 43 \\
\hline SSR-6556 & $\begin{array}{l}\text { 5'-GGTTACTAGCTAATTTTATT-3' } \\
\text { 5'-ATGAACCAGGTCTAATATGA-3' }\end{array}$ & 2 & 19 \\
\hline SSR-6569 & $\begin{array}{l}\text { 5'-GTTAACATCAGTCCCTTTCA-3' } \\
\text { 5'-TTAGAAGGTGAAGGAGAAGC-3' }\end{array}$ & 3 & 38 \\
\hline SSR-6573 & $\begin{array}{l}\text { 5'-TGTATGTAATGGAATCGTAA-3' } \\
\text { 5'-AGATCAGTGGGTTCTGCTCT-3' }\end{array}$ & 3 & 25 \\
\hline SSR-6575 & $\begin{array}{l}\text { 5'-GACATACAACATTTGAACATA-3' } \\
\text { 5'-AAGGAGGTAGATTAAAGATGAG-3' }\end{array}$ & 7 & 58 \\
\hline SSR-6577 & $\begin{array}{l}\text { 5'-GAACTTGATAGGATCCTAGA-3' } \\
\text { 5'-TTCTGGTATGCACTGAGGGA-3' }\end{array}$ & 4 & 63 \\
\hline SSR-6581 & $\begin{array}{l}\text { 5'-GAATTCCTCATCAACAAGTT-3' } \\
\text { 5'-GTGTTCAGCTTTACTTTACTAG-3' }\end{array}$ & 2 & 23 \\
\hline
\end{tabular}

Cotinued on next page 


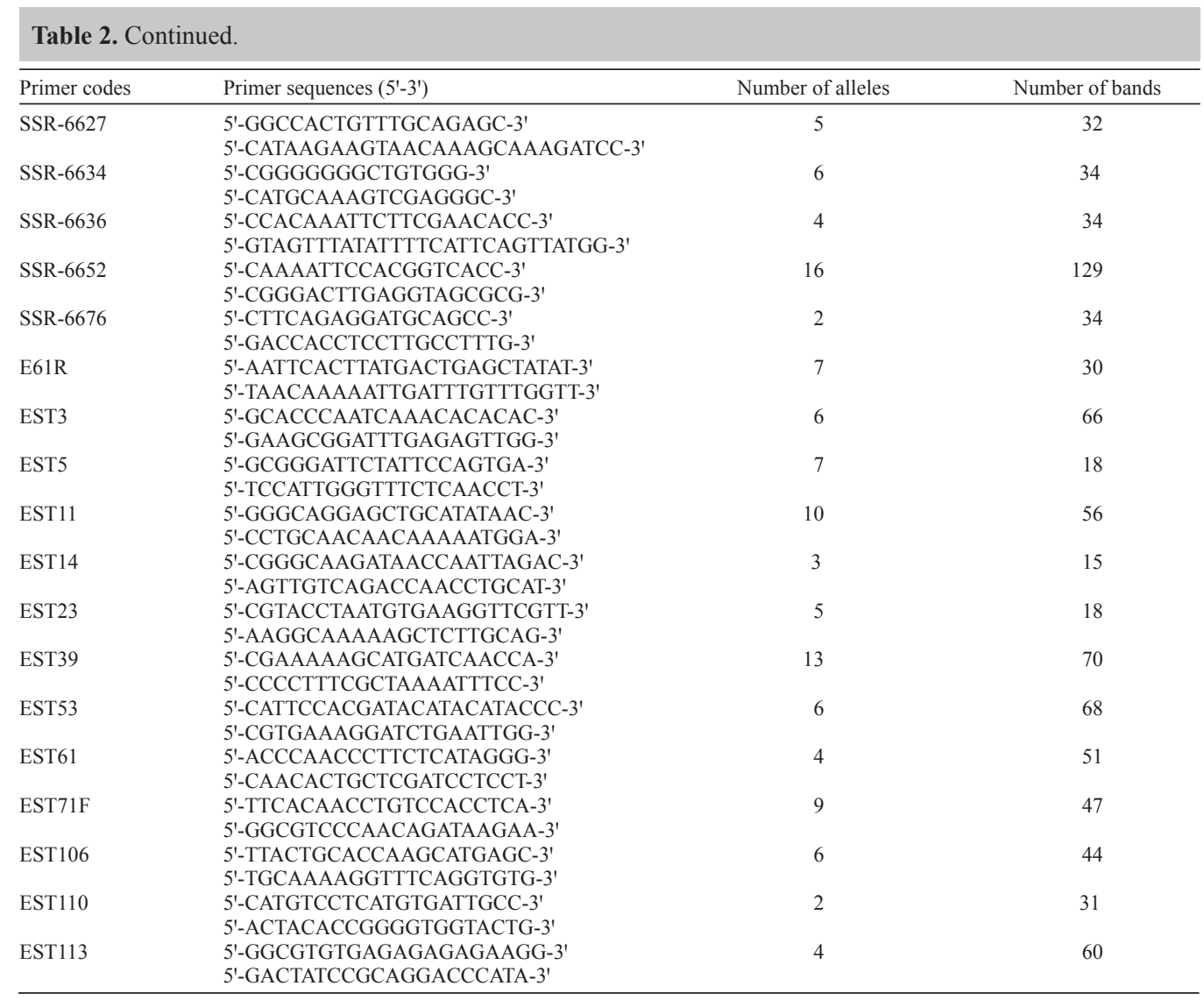

primers generated a total of 2159 bands across the selected genotypes, among them, and 225 (10.4\%) were polymorphic. Five SSR primers did not show any polymorphism between varieties, and therefore, they were excluded in the analysis. The primers SSR-6652 and SSR-6211 amplified the highest (129) and lowest (10) number of polymorphic bands, respectively, across the DNA samples.

The number of alleles varied from 1 to 16 (Table 2). The allele frequency ranged from 0.60 to 0.95 with a mean of 0.79 among the varieties. The genetic diversity varied from 0.08 to 0.42 with an average of 0.28 . The polymorphic information content (PIC) representing the allele diversity for a specific locus varied from 0.08 to 0.33 with a mean of 0.23 . The SSR primer MS-139 gave the highest allele frequency but the lowest genetic diversity and the PIC in the varieties used in these studies (Table 3).

\section{Genetic variation among varieties}

The first group in the dendrogram (Figure 1) included mainly the local varieties, except ISRA-2065, resulting from the cross between Mouride and 58-77 (local variety) and encompassed several subgroups. The local variety 58-80 remained isolated on the top of the dendrogram forming an individual subgroup sharing $25 \%$ dissimilarity with the rest 


\begin{tabular}{|c|c|c|c|}
\hline Primer codes & Allele frequency & Genetic diversity & PIC \\
\hline CP31,CP32 & 0.68181818 & 0.359504 & 0.276287 \\
\hline SSR-6209 & 0.71818182 & 0.342975 & 0.268153 \\
\hline SSR-6211 & 0.84848485 & 0.22865 & 0.191466 \\
\hline SSR-6243 & 0.86363636 & 0.235537 & 0.207798 \\
\hline SSR-6257 & 0.75454545 & 0.364463 & 0.295969 \\
\hline SSR-6258 & 0.77272727 & 0.342975 & 0.281273 \\
\hline SSR-6284 & 0.91818182 & 0.147934 & 0.135416 \\
\hline SSR-6292 & 0.666666667 & 0.424242 & 0.331449 \\
\hline SSR-6302 & 0.86363636 & 0.235537 & 0.207798 \\
\hline SSR-6304 & 0.76515152 & 0.350551 & 0.287177 \\
\hline SSR-6314 & 0.88181818 & 0.207438 & 0.185331 \\
\hline SSR-6323 & 0.88181818 & 0.207438 & 0.185331 \\
\hline SSR-6876 & 0.80681818 & 0.275826 & 0.227668 \\
\hline SSR-6906 & 0.79545455 & 0.278926 & 0.229249 \\
\hline SSR-6531 & 0.85454545 & 0.221488 & 0.187467 \\
\hline SSR-6533 & 0.72727273 & 0.358678 & 0.289007 \\
\hline SSR-6540 & 0.79545455 & 0.28719 & 0.234577 \\
\hline SSR-6545 & 0.67045455 & 0.395661 & 0.308246 \\
\hline SSR-6550 & 0.8506 & 0.229044 & 0.197432 \\
\hline SSR-6553 & 0.65909091 & 0.415289 & 0.323351 \\
\hline SSR-6556 & 0.8636 & 0.2355 & 0.2078 \\
\hline SSR-6569 & 0.60606061 & 0.471074 & 0.32177 \\
\hline SSR-6573 & 0.74242424 & 0.334711 & 0.263122 \\
\hline SSR-6575 & 0.86363636 & 0.230579 & 0.2017 \\
\hline SSR-6577 & 0.71818182 & 0.376033 & 0.29479 \\
\hline SSR-6581 & 0.9545 & 0.0868 & 0.0830 \\
\hline SSR-6627 & 0.8485 & 0.22865 & 0.191466 \\
\hline SSR-6634 & 0.82467532 & 0.263872 & 0.2204 \\
\hline SSR-6636 & 0.7727 & 0.3512 & 0.2896 \\
\hline SSR-6652 & 0.79261364 & 0.289514 & 0.239598 \\
\hline SSR-6676 & 0.7727 & 0.3512 & 0.2896 \\
\hline EST-3 & 0.93939394 & 0.112948 & 0.105884 \\
\hline EST-5 & 0.88181818 & 0.197521 & 0.172094 \\
\hline EST-11 & 0.74242424 & 0.347567 & 0.276544 \\
\hline EST-14 & 0.82954545 & 0.269628 & 0.227706 \\
\hline EST-23 & 0.89772727 & 0.177686 & 0.158737 \\
\hline EST-39 & 0.77272727 & 0.307556 & 0.249043 \\
\hline EST-53 & 0.81060606 & 0.276171 & 0.227499 \\
\hline EST-61 & 0.89393939 & 0.18595 & 0.166203 \\
\hline EST-71 & 0.83884298 & 0.249812 & 0.21123 \\
\hline EST-106 & 0.74545455 & 0.352066 & 0.280401 \\
\hline EST-110 & 0.70454545 & 0.415289 & 0.328884 \\
\hline EST-113 & 0.68181818 & 0.396694 & 0.313093 \\
\hline E61R & 0.8182 & 0.2975 & 0.2533 \\
\hline Mean & $0.7953 \pm 0.0819$ & $0.2898 \pm 0.0867$ & $0.2380 \pm 0.0599$ \\
\hline
\end{tabular}

of the group. In the second subgroup, the local variety 58-77 showed a high coefficient of dissimilarity with the others belonging to the same subgroup. The inbreed line ISRA2065 and the local variety 58-184 were also isolated, whereas 58-74F and 58-191 were clustered together. The third subgroup included 58-78 and 58-153.

In the second group, the Ndoute varieties were clustered in the same subgroup but Bambey 21 was separate like Baye Ngagne. The inbred lines Mougne and Ndiambour formed a subgroup as Diongoma and Melakh with a low coefficient of dissimilarity. The inbred line Yacine was in the same subgroup than the local varieties 58-3 and 58-53. The last subgroup included the inbred line Mouride and the local varieties 58-57 and Ndiaga Aw. 


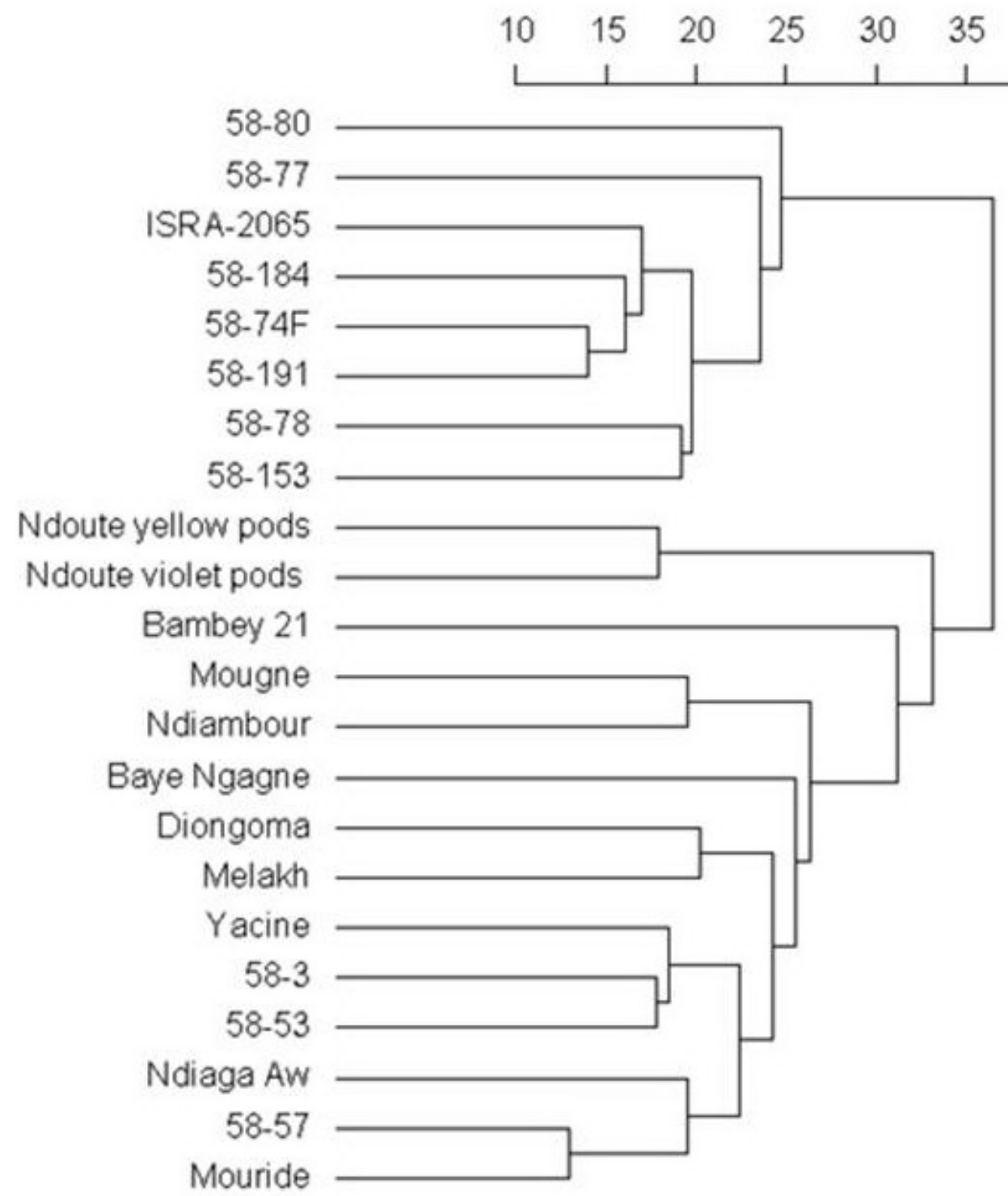

Figure 1. Dendrogram showing similarities between 22 cowpea varieties based on microsatellite markers.

\section{DISCUSSION}

Understanding genetic variation is very relevant for germplasm management by identifying putative redundancies, genetic contamination and developing core collection in order to provide raw material to breeders and farmers to improve productivity through plant breeding. This approach is a valuable tool for the Senegalese cowpea germplasm managers due to the fact that naming accessions by traditional farmers is problematic. Local varieties were 
named based on pod, seed and plant characteristics (color, size, time to maturity), productivity, name of people (introducer) or locality, etc. Therefore, same variety/cultivar having same phenotypic characters may have different names depending on the localities and the ethnic groups. In addition, assessing genetic diversity is a relevant issue as it was recently reported that a long-term conserved germplasm can induce changes in genetic diversity leading to genetic erosion (Cieslarová et al., 2010).

The low level of polymorphism detected in our study is in agreement with previous series reported by several cowpea researchers and may be the result of a bottleneck induced by a single domestication event in this crop (Li et al., 2001; Tosti and Negri, 2002; Badiane et al., 2004; Diouf and Hilu, 2005) in addition to its inherent nature of self-pollination mechanism. The number of alleles amplified in this study ranged from 1 to 16, respectively, in SSR-6251 and SSR-6652, which was higher than that previously reported on the same germplasm which ranged from 1 to 9 (Diouf and Hilu, 2005). In contrast, Asare et al. (2010) reported 4 to 13 alleles in cowpea collected from Ghana, while Sawadogo et al. (2010) reported 5 to 12 alleles in cowpea collected from Burkina Faso using cross species SSRs from Medicago. These findings were in agreement with recent reports on the number of alleles detected using SSR makers in other legumes, such as, 14 to 67 alleles in chickpea (Upadhyaya et al., 2008), 9 to 14 in alfalfa (Mengoni et al., 2000), 1 to 9 in yardlong bean (Tantasawat et al., 2010), 11 to 26 in soybean (Rongwen et al., 1995) and 3 to 12 in pea (Sarikamis et al., 2010). The products amplified by primers SSR-6251 and SSR-6652 showed a high similarity with resistance gene protein analogs of Phaseolus vulgaris, Lens culinaris, Medicago truncatula, M. sativa, Pisum sativum suggesting a synteny between these species and cowpea. These findings should help to quickly identify these genes since the whole genome of some of these legume crops has been sequenced. In fact, most of the SSR primers used in this study were derived from the sequences that are homologous to resistance genes or SSRs in ESTs.

Twenty-two cowpea local cultivars and inbred lines formed two distinct clusters when cluster analysis was done based on the data generated using 44 SSR makers (Figure 1). Most of the local varieties from Senegal were clustered in the same group while the second group included local varieties and inbred lines, which had at least one of the parents from local varieties of Senegal. The local varieties 58-153 and 58-78 shared several morphological characteristics such as bicolor white flowers and white seeds but they are prostrate and semi-erect, respectively, and were supported by a strong coefficient of similarity with SSR data. In contrast, the higher coefficient of similarity between 58-191, 58-74F and 58-184 correlated with the large number of morphological characters shared between these varieties and their close relationship. The inclusion of the improved genotype ISRA-2065 in this group can be related to one of its parent 58-77.

The strong grouping of Ndoute yellow pod and Ndoute violet pod was in agreement with the several morphological characteristics (flower color, seed color and weight, growth pattern) shared between them and their susceptibility to day length and many diseases such as bacterial blight [caused by Xanthomonas campestris pv. vignicola (Burkholder) dye], Cowpea aphid-borne mosaic potyvirus, the parasitic weed Striga gesneioides (Willd.) Vatke, and for insect pests like aphid (Aphis craccivora Koch), flower thrips (Megalurothrips sjostedti Trybom), the hairy caterpillars (Amsacta moloneyi) and to the cowpea storage weevil [Callosobruchus maculatus (F.)] (Table 1). These results suggest that the two varieties have a common parent but mutation probably affecting the gene involved in anthocyanin biosynthesis 
occurred during evolution that changed the pod color from yellow to violet. This phenomenon may also be due to retro-transposon sitting next to the gene controlling anthocyanin biosynthesis as previously reported in grape (Morgante et al., 2007). The variety Mouride and one of its parents 58-57 also belong to the same subgroup and are similar at the morphological level due to several characteristics (seeds color and weight, productivity and resistance to bacterial blight). However, 58-57 showed bicolor or white flowers, short pods, cream and brown-eyed seeds, have indeterminate growth pattern, prostrate and susceptible to Striga. Mouride also has an indeterminate growth pattern, but semi-erect growth habit, and the same grain characteristics. Ndiaga Aw differs from 58-57 only in seed color, which is red and that is reflected by their clustering in the same subgroup. In previous studies based on RAPD data (Diouf and Hilu, 2005), Mouride and Mougne were grouped together, despite the fact that these two varieties showed different morphological characteristics. In contrast, studies by the same authors based on SSR markers clustered them in a separate group, although analysis of combined RAPD and SSR data placed them in the same cluster. These two inbred lines fall into the same cluster in the present study, although they are not closely clustered together.

The improved varieties Mougne and Ndiambour resulting from different crosses were in the same group in the dendrogram based on SSR data. They also differ in flower and grain characteristics although they have a similar growth pattern (indeterminate, prostrate) and reaction to diseases (virus, bacterial blight and Striga) and insects (aphids and bruchids). Ndiambour has bicolor flowers, cream beige-eyed seeds and susceptible to bacterial blight. In contrast Mougne, has bicolor or white flowers, seeds pitted gray on cream background but resistant to bacterial blight. Melakh and Diongoma, both with white flowers and dark green leaves, derived from crosses between Senegalese and Nigerian (IITA) varieties are closely clustered together. Melakh is a prostrate variety, has an indeterminate growth pattern, white light brown-eyed seed, susceptible to Striga, bacterial blight, bruchid, but resistant to greenfly. However, Diongoma has an erect stem, determinate growth pattern, white beige-eyed seeds, resistant to bacterial blight and Striga, but susceptible to aphid and bruchid. The inbred line Bambey 21 stands isolated as it has different morphological and grain characteristics. In addition, it does not share any ancestry with the other inbred lines. It is interesting to see the inbred line Yacine placed somewhere between Melakh and Ndiaga Aw in the second cluster, indicating its ancestry from Melakh and Ndiaga Aw revealed by SSR analysis also.

Genomic microsatellites have been demonstrated to be a powerful tool for assessing genetic diversity among cowpea varieties. The grouping of the varieties was in agreement with the pedigree data of the local cultivars and inbred lines, revealing genetic diversity of cultivated cowpea in Senegal. It also revealed the existence of some important genetic diversity among local varieties not yet exploited for cowpea improvement in Senegal. The most widely cultivated varieties (Melakh, Yacine) and the least important (Mouride, Diongoma, Ndiambour) tend to have a narrow genetic background as they are related to two landraces (58-57 and Ndiaga Aw). Future investigations need to include a wider number of Senegalese germplasm and perhaps additional informative SSR markers to assess the genetic relationship among accessions for a rational exploitation in breeding improved varieties.

\section{ACKNOWLEDGMENTS}

The authors would like to thank the Kirkhouse Trust for supporting this study. They 
would like also to thank the anonymous reviewers for their constructive suggestions and valuable comments.

\section{REFERENCES}

Asare AT, Gowda BS, Galyuon IKA, Aboagye LL, et al. (2010). Assessment of the genetic diversity in cowpea [Vigna unguiculata (L.) Walp.] germplasm from Ghana using simple sequence repeat markers. Plant Genet. Res. Char. Util. 8: $142-150$.

Ayres NM, McClung AM, Larkin PD, Bligh HFJ, et al. (1997). Microsatellites and a single nucleotide polymorphism differentiate apparent amylase classes in an extended pedigree of US rice germplasm. Theor. Appl. Genet. 94: 773781.

Badiane FA, Diouf D, Sané D, Diouf O, et al. (2004). Screening cowpea [Vigna unguiculata (L.) Walp.] varieties by inducing water deficit and RAPD analyses. Afr J. Biotechnol. 3: 174-178.

Barkley NA, Dean RE, Pittman RN, Wang ML, et al. (2007). Genetic diversity of cultivated and wild-type peanuts evaluated with M13-tailed SSR markers and sequencing. Genet. Res. 89: 93-106.

Chen X, Temnykh S, Xu Y, Cho YG, et al. (1997). Development of a microsatellite framework map providing genomewide coverage in rice (Oryza sativa L.). Theor. Appl. Genet. 95: 553-567.

Choumane W, Winter P, Weigand F and Kahl G (2000). Conservation and variability of sequence tagged microsatellites sites (STMSs) from chickpea (Cicer aerietinum L.) within the genus Cicer. Theor. Appl. Genet. 101: 269-278.

Cieslarová J, Smýkal P, Dockalová Z, Hanácek P, et al. (2010). Molecular evidence of genetic diversity changes in pea (Pisum sativum L.) germplasm after long-term maintenance. Genet. Res. Crop. Evol. 58: 439-451.

Diouf D (2011). Recent advances in cowpea [Vigna unguiculata (L.) Walp.] "omics" research for genetic improvement. Afr. J. Biotechnol. 10: 2803-2810.

Diouf D and Hilu KW (2005). Microsatellites and RAPD markers to study genetic relationship among cowpea breeding lines and local varieties in Senegal. Genet. Res. Crop Evol. 52: 1057-1067.

Ehlers JD and Hall AE (1996). Genotypic classification of cowpea based on responses to heat and photoperiod. Crop Sci. 36: 673-679.

Fang J, Chao CCT, Roberts PA and Ehlers JD (2007). Genetic diversity of cowpea [Vigna unguiculata (L.) Walp.] in four West African and USA breeding programs as determined by AFLP analysis. Genet. Res. Crop Evol. 54: 1197-1209.

Fatokun CA, Danesh D, Young ND and Stewart EL (1993). Molecular taxonomic relationships in the genus Vigna based on RFLP analysis. Theor. Appl. Genet. 86: 97-104.

Fotso M, Azanza JL, Pasquet R and Raymond J (1994). Molecular heterogeneity of Cowpea (Vigna unguiculata Fabaceae) seed storage proteins. Plant Syst. Evol. 191: 39-56.

Ghalmi N, Malice M, Jacquemin JM, Ounane SM, et al. (2010). Morphological and molecular diversity within Algerian cowpea (Vigna unguiculata (L.) Walp.) landraces. Genet. Res. Crop Evol. 57: 371-386.

Gupta SK and Gopalakrishna T (2010). Development of unigene-derived SSR markers in cowpea (Vigna unguiculata) and their transferability to other Vigna species. Genome 53: 508-523.

Hegde VS and Mishra SK (2009). Landraces of cowpea, Vigna unguiculata (L.) Walp., as potential sources of genes for unique characters in breeding. Genet. Res. Crop Evol. 56: 615-627.

Hong Y, Chen X, Liang X, Liu H, et al. (2010). A SSR-based composite genetic linkage map for the cultivated peanut (Arachis hypogaea L.) genome. BMC Plant Biol. 10: 17.

Langyintuo AS, Lowenberg-DeBoer J, Faye M, Lamber D, et al. (2003). Cowpea supply and demand in West and Central Africa. Field Crop. Res. 82: 215-231.

Li CD, Fatokun CA, Ubi B, Singh BB, et al. (2001). Determining genetic similarities and relationships among cowpea breeding lines and cultivars by microsatellite markers. Crop Sci. 41: 189-197.

Mengoni A, Gori A and Bazzicalupo M (2000). Use of RAPD and microsatellite (SSR) variation to assess genetic relationships among population of tetraploid alfalfa, Medicago sativa. Plant Breed. 118: 311-317.

Mignouna HD, Ng HD, Ikca J and Thottapilly G (1998). Genetic diversity in cowpea as revealed by random amplified polymorphic DNA. J. Genet. Breed. 52: 151-159.

Morgante M, De Paoli E and Radovic S (2007). Transposable elements and the plant pan-genomes. Curr. Opin. Plant Biol. 10: 149-155.

Nkongolo KK (2003). Genetic characterization of Malawian cowpea [Vigna unguiculata (L.) Walp.] landraces: diversity and gene flow among accessions. Euphytica 129: 219-228.

Panella L and Gepts P (1992). Genetic relationships within [Vigna unguiculata (L.) Walp.] Based on isoenzyme analyses. Genet. Res. Crop Evol. 39: 71-88. 
Pasquet RS (1993). Variation at isoenzyme loci in wild [Vigna unguiculata (L.) Walp.] (Fabaceae, Phaseoleae). Plant Syst. Evol. 186: 157-173.

Perrino P, Laghetti G, Spagnoletti Zeuli PL and Monti LM (1993). Diversification of cowpea in the Mediterranean and other centers of cultivation. Genet. Res. Crop Evol. 40: 121-132.

R Development Core Team (2011). A Language and Environment for Statistical Computing. R Foundation for Statistical Computing, Vienna. Available at [http://www.R-project.org]. Accessed December 22, 2011.

Rongwen J, Akkaya MS, Bhagwat AA, Lavi U, et al. (1995). The use of microsatellite DNA markers for soybean genotype identification. Theor. Appl. Genet. 90: 43-48.

Sarikamis G, Yanmaz R, Ermis S, Bakir M, et al. (2010). Genetic characterization of pea (Pisum sativum) germplasm from Turkey using morphological and SSR markers. Genet. Mol. Res. 9: 591-600.

Sawadogo M, Ouedraogo JT, Gowda BS and Timko MP (2010). Genetic diversity of cowpea [Vigna unguiculata (L.) Walp.] culivars in Burkina Faso resistance to Striga gesnerioides. Afri. J. Biotechnol. 9: 8146-8153.

Senior ML, Murphy JP, Goodman MM and Stuber CW (1998). Utility of SSRs for determining genetic similarities and relationships in maize using an agarose gel system. Crop Sci. 38: 1088-1098.

Simon MV, Benko-Iseppon AM, Resende LV, Winter P, et al. (2007). Genetic diversity and phylogenetic relationships in Vigna Savi germplasm revealed by DNA amplification fingerprinting. Genome 50: 538-547.

Spencer MM, Ndiaye MA, Gueye M, Diouf D, et al. (2000). DNA-based relatedness of cowpea (Vigna unguiculata (L.) Walp.) genotypes using DNA amplification fingerprinting. Physiol. Mol. Biol. Plants 6: 81-88.

Tantasawat P, Trongchuen J, Prajongjai T, Seehalak W, et al. (2010). Variety identification and comparative analysis of genetic diversity in yardlong bean (Vigna unguiculata spp. sesquipedalis) using morphological characters, SSR and ISSR analysis. Sci. Hortic. 124: 204-216.

Tautz D (1989). Hypervariability of simple sequences as a general source for polymorphic DNA markers. Nucleic Acids Res. 17: 6463-6471.

Timko MP and Singh BB (2008). Cowpea, A Multifunctional Legume. In: Genomics of Tropical Crop Plants (Moore PH and Ming R, eds.). Springer Science+Business Media, New York, 227-258.

Timko MP, Ehlers JD and Roberts PA (2007). Cowpea. In: Pulses, Sugar and Tuber Crops, Genome Mapping and Molecular Breeding in Plants (Kole C, ed.). Vol. 3. Springer-Verlag, Berlin, Heidelberg, 49-67.

Tosti N and Negri V (2002). Efficiency of three PCR-based markers in assessing genetic variation among cowpea (Vigna unguiculata subsp. unguiculata) landraces. Genome 45: 268-275.

Uma MS, Hittalamani S, Murthy BCK and Viswanatha KP (2009). Microsatellite DNA marker aided diversity analysis in cowpea [Vigna unguiculata (L.) Walp.]. Indian J. Genet. Plant Breed. 69: 35-43.

Upadhyaya HD, Dwivedi SL, Baum M, Varshney RK, et al. (2008). Genetic structure, diversity, and allelic richness in composite collection and reference set in chickpea (Cicer arietinum L.). BMC Plant Biol. 8: 106.

UPOV-BMT: BMT/36/10 (2002). Progress Report of the 36th Session of the Technical Committee, the Technical Working Parties and Working Group on Biochemical and Molecular Techniques and DNA-Pofiling in Particular. Geneva.

Vaillancourt RE and Weeden NF (1992). Chloroplast DNA polymorphism suggests Nigerian center of domestication for the cowpea, Vigna unguiculata (Leguminosae). Am. J. Bot. 79: 1194-1199. 